\title{
Models of Political Representation: A Study of Village Chief Elections and Candidacies
}

\author{
Arga Pribadi Imawan ${ }^{1}$ and Haryanto ${ }^{2}$
}

Received: 18 March 2019 | Accepted: 12 October 2019 | Published: 12 November 2019

\begin{abstract}
Electoral contestations at the village level have seemingly been an 'isolated' phenomenon in social and political studies. Most studies have focused on local executive and legislative elections, as well as the political representations they involve. This article, instead, looks to the village level, examining the political representation involved in the village chief elections of Dlingo, Bantul, Yogyakarta. Qualitative research methods (interviews, live-in observations) were conducted before, during, and after the elections. This study finds that the rise of the two candidates could be traced to various factors and tendencies, and that the models of political representation at the village chief (executive) level are similar to those in legislature.
\end{abstract}

Keywords: models of political representation, village chief elections, village chief candidates

\section{Models of Political Representation and General Elections}

This article focuses on the politics of representation and attempts to understand how candidates use particular models. More specifically, this article focuses on how village chief candidates emerge and are elected. The framework of political representation is important in this study, as it contributes significantly to discussion of candidates' rise and election.

Arga Pribadi Imawan is a research assistant at the Research Centre for Politics and Government (PolGov), Faculty of Social and Political Sciences, Universitas Gadjah Mada. He has written numerous opinion columns in the mass media and conducted various studies of elections, identity politics, and border issues. He may be contacted at: argaimawan@gmail.com

2 Haryanto is Professor of Politics, Department of Politics and Government, Universitas Gadjah Mada. He has produced numerous academic journal articles and books, focusing primarily on elites, political movements, and identity politics. He may be contacted at haryanto_yogya@yahoo.com. 
Existing studies of political representation have viewed political representation from a range of perspectives, including gender (Aguilar, Cunow, \& Desposato, 2015; Lühiste \& Kenny, 2016; Hasunuma, 2019; Celis, 2013; Prihatini, 2019; Koyuncu, \& Sumbas, 2016); ethnicity (Zhanarstanova \& Nechayeva, 2016; Martin, 2019; Van der Zwan \& Lubbers, 2016), geography (Scott, 2009; Jennes \& Persyn, 2015), and social class (Carnes \& Lupu, 2015). These studies have tended to emphasise three types of political representation, namely descriptive representation, symbolic representation, and substantive representation (Pitkin, 1967).

These studies have attempted to understand how the rights of minorities (including gender minorities, ethnic minorities, class minorities, or geographic minorities) can be protected. One study in Turkey, for example, has examined women mayoral candidates using the logics of substantive and descriptive representation (Koyuncu \& Sumbas, 2016). Another study in Latin America contributed further to these concepts, but limited itself to the question of ethnicity (Carnes \& Lupu, 2015). It may thus be concluded that studies of political representation have tended to limit themselves to one or two of the above-mentioned concepts.

Studies of political representation have tended to focus on legislature, as candidates are seen as representing specific groups/ territories/genders. However, this does not mean that Pitkin's concepts cannot be used to understand political representation within the executive branch. This can be seen, for example, in the above-mentioned study by Koyuncu \& Sumbas (2016), who found that women mayoral candidates could be understood through their symbolic representation as being easy to access and willing to represent women and treat them justly. Similarly, Nasrudin \& Nurdin (2018) have used Pitkin's concept of political representation to investigate Jakarta's 2018 gubernatorial elections, finding that political representation (more specifically, identity politics) contributed significantly to electoral victory.

In this paper, the concepts of political representation are used 
to investigate the village chief elections in Dlingo, a village in Bantul Regency, Yogyakarta, Indonesia. Candidates' decision to run for village chief, as well as their electoral contestations, will be discussed using Pitkin's concept of political representation. Candidates used descriptive, symbolic, and substantive representation, distinguishing them from each other and (perhaps) from candidates in previous studies. In Dlingo, neither candidate came from a minority background. Rather, both were members of the socio-cultural majority-in this case, members of the religious organisation Nahdlatul Ulama (NU).

The first candidate, Kastoyo, was put forth by his padukuhan (a sub-village administrative unit) to promote its interests. All of the residents of this padukuhan united to provide support for him and his candidacy, and in return Kastoyo promised to promote its interests. He promised, for example, to repair the roads - something that has yet to be realised (Kastoyo, interview, October 4, 2018) . $^{3}$ The second candidate, Agus Purnomo ${ }^{4}$, was chosen to represent the $\mathrm{NU}$ after a series of discussions between village elders and other NU members. As such, at a glance it may appear that Agus Purnomo would promote the organisation's interests.

This article also details the electoral journeys of these candidates. It will narrate how they were chosen to contest the election, the agendas they developed, their efforts to promote these agendas during their campaigns, and the results of the election. For this, it has relied on primary and secondary data. Primary data were collected through interviews with local residents and live-in observations. Secondary data, meanwhile, were collected from journal articles, news stories, and village documents, and used to validate the primary data as well as elucidate elements that remained unclear. At the theoretical level, this narrative will provide a means of understanding candidates' models of political

Candidate for Dlingo Village Chief (2018-2024).

4 Candidate for Dlingo Village Chief (2018-2024). 
representation and thereby obtaining a better understanding of the concept. At the practical level, this article will narrate the rise of political candidates - something that has only rarely been done.

This article's narrative is interesting because the emergence of village chief candidates has drawn little academic attention. One study that has examined the rise of village chief candidates was conducted by Khaldun (2017), who identified candidate(s) election processes as being strongly informed by village typology. In more traditional villages, village chiefs tend to be selected through discussions between village elders and elites. In transitional villages, meanwhile, numerous residents actively contest the elections, using vote buying and creating tension that could potentially escalate conflict. Elections in modern villages, finally, tend to involve fewer candidates but more professional elections, which can be attributed to residents being more politically open.

Through this study, Khaldun (2017) touched on one aspect of village chief elections, failing to reach beyond the link between candidate selection and village typology. This study did not explore other dimensions of the candidate selection process, such as the basis of candidates' political support. It is important to elaborate on candidates' political representation to promote a more comprehensive understanding of how they are selected and elected. Other studies have not touched on this topic; this study, thus, is intended to fill that gap.

This article is divided into several sections. It will begin by describing the conceptual framework used in this study, as well as the background that informed candidates' selection. It will then provide some information about the village, the candidates, and relevant events that occurred before and after the election, focusing particularly on the dynamics of village chief selection in Dlingo. It will show that the two village chief candidates in Dlingo used opposite models of political representation, with the one receiving the support of a religious organisation and the other seeking to promote territorial ambitions. 


\section{Models of Political Representation}

Generally, studies of the models of political representation have referred to the concepts introduced by Pitkin (1967), who identified three models of political representation. The first is descriptive representation, in which a representative is chosen as a substitute for others based on a specific characteristic (gender, class, race, etc.). In essence, representatives are chosen because they resemble those they will represent. Second is symbolic representation, which emphasises the use of various symbols to depict or represent something. These symbols are used to translate the characteristics of the people being represented. For example, candidates may adopt the symbols of religion and nationalism (Cahasta, 2017). Third is substantive representation, in which representatives emphasise that their activities are all done to promote the substantive interests of those they represent. For example, candidates from religious backgrounds may emphasise their involvement in religious activities (Pitkin, 1967; Cahasta, 2017).

Table 1: Models of Political Representation

\begin{tabular}{|l|l|l|r|}
\hline \multirow{2}{*}{ Political Representation } & Acting For & \multicolumn{2}{|c|}{ Standing for } \\
\cline { 2 - 4 } & Substantive & Descriptive & Symbolic \\
\hline
\end{tabular}

These three models of representation may be divided into two mental frameworks, which may be referenced through the terms standing for (traditionally understood as encompassing descriptive and symbolic representation) and acting for (traditionally understood as encompassing substantive representation). ${ }^{5}$ For decades, the

\footnotetext{
Pitkin's distinction between acting for and standing for has resulted in debate. Suseno (2013) identifies descriptive representation as acting for and symbolic and substantive representation as standing for. On the other hand, Cahasta (2017) and Samadhi \& Warouw (2009) identify descriptive and symbolic representation as standing for and substantive representation as acting for.
} 
concepts introduced by Pitkin (1967) have been referenced by social and political scientists in their examinations of political representation.

Over time, Pitkin's concepts have been further explored and subject to criticism. For example, Vierira and Runciman have argued that representation must also encompass ideas such as 1) chosen representatives should resemble those they represent; 2) chosen representatives should act in the interest of those that they represent; 3) chosen representatives should act with the support of those they represent (Ekawati, 2016). The concept was also expanded by Törnquist, Webster, \& Stokke (2009) in their study of popular representation. Seward (in Ekawati, 2016), meanwhile, criticises Pitkin as focusing on representatives over those represented (Ekawati, 2016).

Although his conceptual framework has been criticised, the work of Pitkin (1967) remains relevant for understanding the models of political representation used by executive and legislative candidates. Kurebwa (2015) emphasises that Pitkin's concepts remain necessary as they provide a clear analytical framework and, thus, facilitate the identification of different approaches. Furthermore, Pitkin's framework is a foundational one, facilitating researchers' efforts to identify the factors that contribute to representation. As such, it remains relevant for the current study of village chiefs' political representation, as well as future investigations of executives' political representation at the lowest level.

This article, thus, will apply Pitkin's three models of representation. Mainstream studies have tended to focus on representation within the legislative branch or political bodies; few have examined representation within the executive branch. Pitkin's concepts will be expanded through this article, as it will contribute an understanding of their application at the lowest level. It seeks to identify the models of representation that influence village chief candidates' electoral efforts, and therefore further develop the concept. 


\section{Dlingo Village: Territorial and Social Phenomena}

Dlingo Village is located on the edge of Bantul Regency. It is an expansive village, consisting of ten padukuhan (sub-village administrative units): Pokoh I, Pokoh II, Kahuripan I, Kahuripan II, Dlingo I, Dlingo II, Pakis I, Pakis II, Kebosungu I, and Kebosungu II. Of these, the three largest (both in terms of area and population) are Koripan II, Pakis I, and Kebosungu I.

Despite the village's administrative diversity, the people of Dlingo are highly homogenous. The majority of residents are Muslims; only a small minority (approximately 10 residents) are non-Muslim. Most of the village's Muslim residents follow the teachings of NU, which has its strongest support base in Kebosungu (Abdurrahman, interview, October 8, 2018) ${ }^{6}$. This organisation, having made its first inroads in Kebosungu, spread its teachings throughout the village.

A sizable minority of village residents follow the teachings of Muhammadiyah. Members of the organisation are concentrated primarily in Pakis, with others being found in Pokoh I (Abdurrahman, interview, October 8, 2018). Other religious organisations, such as the Indonesian Institute for Islamic Dakwah (Lembaga Dakwah Islam Indonesia, LDII), contribute further to the Dlingo's religious practices. However, such organisations have few members (Ngadiyono ${ }^{7}$, interview, October 11, 2018). It may thus be concluded that Islamic organisations have contributed significantly to the society and culture of Dlingo, and that residents are influenced by the teachings of these organisations.

Despite this relative homogeneity, however, residents exhibit a high level of social tolerance. During elections, frictions are

\footnotetext{
Ustadz Abdurrahman, Leader of the Kastoyo Campaign Team.

Member of the Kastoyo Campaign Team.
} 
minimal, and where they occur, they are handled easily (Malik ${ }^{8}$, interview, October 11, 2018).

\section{The Incumbent in Dlingo Village}

Before the 2018 election, Dlingo was under the leadership of Bahrun Wardoyo, a resident of Pakis I who had been elected in 2012. His background and campaign are somewhat unique, as Bahrun Wardoyo is a member of Muhammadiyah, rather than the dominant NU and the candidate had limited access to funds during his campaign. This section, thus, will touch on his experiences as part of its background.

Bahrun Wardoyo emerged victorious in the 2012 election because he was able to gain the support of NU leaders and village elders - political kingmakers - from throughout Dlingo. The solidarity that he developed with his campaign team cannot be separated from the perception that he was "representing the common people" (representasi wong cilik), with whom he was believed to be close because of his professional background. He thus gained the full support of many local residents.

The limited availability of funds was not a significant obstacle for Bahrun Wardoyo and his campaign team. The candidate did not only campaign using his personal charisma; they also relied on two particular strategies. First, his team campaigned door-todoor, visiting local residents and mobilising support. No political transactions took place; it was sufficient for the campaign team to identify Bahrun Wardoyo as a common man who sought to become the village chief and transform the village (Ngadiyono, interview, October 11, 2018). Second, the team utilised its limited budget to the best of its abilities, relying on mutual support networks during their campaign activities. During his campaign, Bahrun Wardoyo often sought material support from local residents, some of whom

\footnotetext{
Village Secretary (Sekdes/Carik) of Dlingo.
} 
were willing to provide it. These direct interactions with residents enabled him to become closer with them, to establish a rapport that he continued to maintain (Malik, interview, October 11, 2018).

\section{Incumbent Performance: The Consensus of Village Elites}

As village chief, Bahrun Wardoyo was positively perceived owing to his dedication and his desire to facilitate the management of village funds. This image helped him maintain the social support he needed to perform as village chief. Some residents of Dlingo identified Bahrun Wardoyo's leadership as bringing the village into a new era. He was able, for example, to reduce tensions and increase public electoral participation. This was eased by the nongovernmental organisations that became involved. For example, the Institute for Research and Empowerment (IRE) provided political and election education to village residents. Another organisation, IDEA, helped the village plan its budget, monitor the execution of said budget, and prepare reports (Qoni'ah ${ }^{9}$, October 9, 2018).

Bahrun Wardoyo also provided the village youths with a means of expressing themselves, establishing a community radio station called Sandigita and entrusting its management to local youths. With such programmes, the youths of Dlingo were given new activities, allowing them to break the habit of sitting about or wandering aimlessly (Malik, interview, October 11 2018). To facilitate social interactions, he established wi-fi networks and creating angkringan (roadside food stalls) as gathering places $\left(\right.$ Hariyah $^{10}$, interview, October 9 2018).

Seeking to promote Dlingo and increase public interest, Bahrun Wardoyo established networks with local and national media. Through these networks, he was able to introduce Dlingo at various regency and provincial-level events, as well as receive media

\footnotetext{
9 Chairwoman of the Dlingo Village Family Welfare Program (2012-2018) and wife of incumbent Bahrun Wardoyo.

10 Resident of Dlingo Village.
} 
coverage of the village and its programmes (Ngadiyono, interview, October 11, 2018). This coverage, which highlighted the success of the village's programmes, proves his success in this matter.

Finally, after Bahrun Wardoyo's election, Dlingo began to establish political networks and create deals with political parties. These parties asked Bahrun to help them mobilise support within the village. He did this primarily by mapping the political tendencies (particularly the support bases) of the various padukuhan; for example, if residents of a particular hamlet were more likely to support a specific party, he would recommend that they limit their campaign activities to that hamlet. In return, these parties would support his programmes. For example, when Dlingo was building a mosque near its village hall, these parties contributed significantly to show their gratitude (Malik, interview, October 11, 2018).

Although Bahrun's performance was broadly praised, there were residents who disagreed. They argued, first, that development plans were not properly handled. Several residents indicated that Bahrun would accept any development project offered by outside investors, and as such staff were required to work extra hard. This lack of coordination led to friction, and ultimately multiple projects were not completed. Second was the issue of the village budget. The influx of village funds from the government-totalling Rp 1 billion-was not reflected in local development activities (Bahruddin ${ }^{11}$, interview, October 12, 2018).

Third, most available village funds were used for a cultural event (Gebyar Budaya). Many residents regretted that the village government had spent so much money on this event, which failed to address the real problems and issues experienced by the community, and argued that these funds should have been allocated towards more practical endeavours such as purchasing tractors for farmers or eradicating poverty (Purnomo, interview, October 9, 2018). Fourth, there were issues with budget transparency. Although the allocation

11 Leader of the Agus Purnomo Campaign Team. 
of village funds was posted on the village announcements board, there was no detailed breakdown of how funds were used; only the total amount was specified (Purnomo, interview, October 9, 2018).

Fifth, public facilities such as the village hall were used by outside organisations for their activities. Some residents considered such use of village facilities by non-residents, without the prior approval of residents, to be inappropriate (Bahruddin, interview, October 12, 2018). Sixth, despite being village chief, Bahru Wardoyo was perceived as spending most of his time as an activist for village rights at the national level, and thus only rarely providing services to his own constituents. In other words, some residents were dissatisfied with his attitude.

From the above discussion, it may be concluded that Bahrun Wardoyo's performance as village chief was polarising in Dlingo. Some residents viewed him as having breathed new wind into Dlingo, while other perceived him as having lacked budget transparency and shown limited commitment to his constituents. Overall, however, residents were dissatisfied with Bahrun Wardoyo being generally unavailable to residents. Dissatisfaction peaked after the village hall was used by a major religious organisation for one of its activities. Ultimately, NU leaders and village elders agreed that it was necessary to find a new village chief.

\section{The Selection of the Two Candidates}

Dissatisfaction with the incumbent's performance led to village elders seeking new candidates who could perform as desired. In other words, religious leaders desired a candidate who could would represent NU, the largest Muslim organisation in the village, and its interests. They thus sought to build a consensus, to jointly determine the candidate that they would field in the 2018 election. In reality, however, this process was not as simple as hoped, as there occurred a tug-of-war between various groups' interests. Two candidates were thus fielded, respectively representing organisational and territorial 
ambitions.

\section{Organisational Ambitions}

Consensus building began in June 2018, during the middle of the fasting month, and involved dozens of societal leaders, religious leaders, and padukuhan leaders (Bahruddin; 2018). The process began with a simple question: "In this forum, is there anyone who would like to advance themselves, or to propose another, as a candidate for us to support in the 2018 election?". This question produced a list of 40 potential candidates. Over time, this list was winnowed down to 10 names. Of these, one-Agus Purnomo-gained the most support.

The choice of Agus Purnomo, however, was not without its detractors. Shortly before the gavel was tapped, signifying unilateral support for Agus Purnomo, a religious leader from Kebosungu (Ustadz Abdurrahman) stated his opposition. Abdurrahman proposed another candidate, Kastoyo, a resident of Kebosungu and NU member.

"... I lifted my finger in opposition just as they were going to agree to back Agus. All eyes turned to me, as I was the only one who disagreed with this result. I suggested Kastoyo as a candidate for chief of Dlingo. I suggested Kastoyo for his experience, as well as to promote our padukuhan's ambitions, to ensure that a son of Kebosungu was recorded in our village history" (Abdurrahman, interview, October 8, 2018).

Abdurrahman's proposal, however, faced opposition as Kastoyo was not present. As such, Abdurrahman chose to ask Kastoyo whether he was willing to run for village chief; in order to do so, he requested that the formal declaration of support for Agus Purnomo was delayed. However, members of the forum rejected this proposal, arguing that 1) a decision had to be made immediately, to ensure that they had time to prepare a candidate; and 2) an individual's willingness to become village chief could be ascertained from their forum attendance-as such, the fact that Kastoyo had not attended the forum was evidence that he was unwilling to run for 
village chief.

Ultimately, members of the forum (except for Abdurrahman) agreed that Agus Purnomo would receive the full support of Dlingo's social and religious leaders. As such, this forum was able to fulfil its mission: to find a candidate who could represent the organisational interests of the Nahdlatul Ulama.

\section{Territorial Ambitions}

The elite forum's backing of Agus Purnomo received widespread opposition in Kebosungu. Residents desired to make their mark on the history of the village, and they decided thatwith or without the support of NU-they would propose their own candidate.

As in the meeting of the NU elites, there was significant debate as the people of Kebosungu chose their candidate. However, this was not caused by an abundance of candidates; rather, nobody expressed such a desire. Initially, residents of Kebosungu urged Abdurrahman to run against Agus Purnomo, partly out of concern that the incumbent would seek re-election. The people of Kebosungu believed that only Abdurrahman stood a chance of winning against the incumbent and Agus Purnomo.

Ultimately, it was decided that Abdurrahman-who had guided Agus Purnomo in his religious studies - would pretend to take a form and register himself as a candidate. They believed that, if this were to occur, Agus Purnomo would concede and withdraw from the race out of respect for his teacher.

"... I was only pretending when I took a registration form. Agus Purnomo heard and said he would withdraw from the race. But really, I was just testing the waters, trying to see whether the incumbent would run again, who else would potentially contest the election, and whether I could compete against the incumbent if I were to run." (Abdurrahman, interview October 8, 2018).

Afterwards, however, the situation changed. The incumbent 
made no attempt to contest the village election, instead being backed by the National Mandate Party (Partai Amanat Nasional, PAN) in a legislative election.

This situation significantly benefited the people of Kebosungu, who sought to field their own candidate for village chief. For example, residents of the padukuhan were able to the social networks established by the incumbent's campaign team, including amongst Muhammadiyah members and residents of Kebosungu. In other words, the candidate fielded by Kebosungu would have no less capital than Agus Purnomo. Abdurrahman recognised this, but the residents had yet to deal with their initial problem: who would they field? Ultimately, Kastoyo was chosen as Kebosungu's candidate, and provided access to the incumbent's machine. Thus were Kebosungu's territorial ambitions accommodated, and its candidate prepared to contest the Dlingo's 2018 village chief election.

\section{The Ideas of the Two Village Chief Candidates}

It was thus determined that the Dlingo election would be contested by two candidates: Agus Purnomo and Kastoyo. These two candidates had significantly different backgrounds. Agus Purnomo was a migrant (having been born in Kudus) and had neither previous political experience nor a family history of political activity. Kastoyo, meanwhile, was a native-born resident of Dlingo (specifically, of Kebosungu) and had previous political experience.

These candidates also had different ideas and made different promises during their campaigns. Agus Purnomo emphasised two ideas in his campaign activities, namely budget transparency and religious development. He stated that, if he were elected, he would address the previous government's lack of transparency, inability to complete its programmes, and service problems. He expected that his experiences establishing a company and selling clothing would help him manage the village and his programmes.

Second, Agus Purnomo promised that he would bring balance 
to religion and culture. While promoting cultural development, he would continue to advance religious causes, as he argued that religion has served as a shield against negative outside forces. No less important was transforming public perspectives of the village government and increasing trust (Purnomo, interview, October 8, 2018).

These ideas are evident in Agus Purnomo's mission statement: "Implementing a clean, transparent, and accountable government to create a democratic, religious, independent, and prosperous Dlingo". It is also evident in one point of his campaign's vision: "Improving the quality of life in a religious and educated society". Such ideas had also been expressed by religious leaders such as Abdurrahman and Jaffar.

Kastoyo, meanwhile, sought to create a government wherein people could receive public services without being discrimination. To realise this goal, Kastoyo established the Team of Seven, which was tasked with formulating his campaign's vision and missions, as well as determining an appropriate budget for the campaign. The Team of Seven was led by Abdurrahman, and most members were neighbourhood leaders or other senior officials in the padukuhan (Kastoyo, interview, October 6, 2018). This team produced a memorable slogan: Kastoyo Ngangeni (ngayomi, ngopeni, netepi, Javanese terms that mean 'serves, nurtures, listens'). This was supported by the vision, "To build upon the potential of Dlingo village together with the local people in an atmosphere of ngayomi, ngopeni, netepi, without abandoning culture and religion". The campaign also promised to "Ngayomi all members of society without discrimination, regardless of their cultural, social, political, or religious background".

\section{The Symbols Used by Two Village Chief Candidates}

The candidates in Dlingo had significantly different backgrounds. Agus Purnomo was popularly perceived as a 
religious man, as he graduated from a Madrasah Aliyah (a type of religious school). Owing to his educational background, he was frequently asked to impart religious knowledge and teach children. His campaign was also supported by his previous organisational experiences. Over the years, Agus Purnomo had been involved in various community organisations and institutions. In Kudus, he had led the Mambaul Qur'an pesantren, while in Dlingo he was known as close to the NU leadership. As such, NU leaders in the village perceived him as a good candidate.

Responding to Agus Purnomo's use of NU as his political vehicle, Abdurrahman proposed his own candidate. Several times he attempted to lobby Kastoyo, urging him to run for village chief. Initially, Kastoyo was unwilling to become village chief, but he ultimately agreed to run in order to realise the ambitions of his padukuhan. He was also unhappy with Agus Purnomo's use of NU as a political vehicle.

"... I disagreed with the candidate's use of the NU as a means of getting support. For me, NU was far too big to be used in village elections." (Kastoyo, interview, October 6, 2018).

Kastoyo's background differed significantly. Kastoyo was a farmer, and as such was perceived as representing the common people(wong cilik). Furthermore, he had previous political experience, having served on a campaign team and as party treasurer; one of his ancestors, meanwhile, had been an important village administrator in the 1940s. This background contributed significantly to Kastoyo's candidacy.

\section{Models of Political Representation Used by Village Chief Candidates}

The above narrative provides sufficient background for understanding the rise of the candidates as well as identifying the models of representation they used. Briefly, the narrative of the incumbent shows that he had been elected partly because he shared 
the same social class with his constituents. In other words, Bahrun Wardoyo had been standing for (had descriptively and symbolically represented) his constituents. ${ }^{12}$ What about the candidates in the 2018 election? What was their model of representation? Acting for, standing for, or a combination of both? The following discussion will focus on the models of representation used by Agus Purnomo and Kastoyo.

\section{Models of Political Representation: The Two Candidates in Dlingo}

As discussed above, Agus Purnomo began his campaign after receiving the recommendation of the local NU. From a formal perspective, Agus Purnomo had received a mandate from (been legitimised by) its senior figures. These religious leaders, the ustadz Jaffar and Bahruddin, also contributed significantly to the formulation of his campaign's vision and missions as well as its strategies.

From a descriptive perspective, Agus Purnomo may be understood as representing NU as a religious organisation. Given the popular perception of Agus Purnomo being a pious man and devout follower of NU's teachings, it is not surprising that the candidate used religious symbols during his campaign. Religious considerations were also evident in his campaign's vision and mission, which had been formulated in part by ustadz Bahruddin.; take, for example, the stated desire to improve "the quality of life in a religious and educated society". Furthermore, during his campaign activities, Agus Purnomo presented himself as a pious man, including through nightly congregational prayers. ${ }^{13}$

12 Descriptive representation is shown in the forefronting of Bahrun Wardoyo's profession as a tailor and his desire to lead the common people. Meanwhile, symbolic representation can be seen in the use of nationalist symbols. Bahrun efforts to embrace members of both Muhammadiyah and Nahdlatul Ulama - a majority in Dlingo - shows his desire to avoid pigeonholing his supporters.

13 Congregational prayers are generally used by Muslims to facilitate their activities and to realise their desires. 
Kastoyo's candidacy, meanwhile, was entirely unexpected, and the candidate himself had not shown a significant desire to become village chief. Despite being a member of NU, he had not attended the meeting where organisational elite had chosen their favoured candidate, nor had he participated in other discussions. However, as stated previously, Kastoyo received the support of the people of Kebosungu and the backing of Abdurrahman. Because he worked as a farmer, he was also framed as one of the "common people", the wong cilik.

Kastoyo was thus seen as standing for a specific social class and territory, more specifically the farmers of Dlingo and the people of Kebosungu. In return, he received their full support. In terms of symbolic representation, meanwhile, he adopted nationalist symbols during his campaign. As with the incumbent, he did not rely on his religious affiliations, promising not to advance the interests of a specific religious group but rather to embrace all residents equally. Implicitly, thus, Kastoyo was presented as a candidate who, while religious, was also a nationalist.

The candidate was also seen as acting for the common people, the wong cilik from whom he received his mandate and his formal legitimacy. For this, the vision and mission formulated by his Team of Seven accommodated the interests of the wong cilik. Take, for example, one of Kastoyo's missions: "To work together to utilise all of the potential in Dlingo, including its natural resources (tourism, forestry, agriculture, and land), as well as its human resources (training staff and residents in accordance with their needs) to improve the economy and productivity."

The candidates' models of representation can be seen in the following table. 
Table 2: Comparison of Candidates' Models of Political Representation in the 2018 Dlingo Elections

\begin{tabular}{|c|c|c|c|}
\hline \multirow{2}{*}{ Candidate } & Acting For & \multicolumn{2}{|c|}{ Standing for } \\
\cline { 2 - 4 } & Substantive & Descriptive & Symbolic \\
\hline $\begin{array}{c}\text { Agus } \\
\text { Purnomo }\end{array}$ & $\begin{array}{c}\text { Religious } \\
\text { Group }\end{array}$ & $\begin{array}{c}\text { Religious Group } \\
- \text { NU (Religious } \\
\text { Organisation) }\end{array}$ & Religious \\
\hline Kastoyo & Social Class & $\begin{array}{c}\text { Territory and Social } \\
\text { Class }\end{array}$ & $\begin{array}{c}\text { Nationalist/ } \\
\text { Ideological }\end{array}$ \\
\hline
\end{tabular}

The above table presents a comparison of the models of political representation used by the two candidates. It can clearly be seen that Agus Purnomo utilised religion as the basis of his political representation. Kastoyo, meanwhile, sought to represent a specific social class and territory, as evidenced in his ideas, constituents, and experiences.

\section{Conclusion: Two Models of Political Representation}

This study of the village chief candidates in Dlingo Village, Bantul Regency, Yogyakarta, in 2018 has identified two models of political representation. One candidate, Agus Purnomo, relied on religion (social identity) as the basis of his political representation. This can be seen, for example, in his religious background as well as the fact that he was selected by a forum of elites to represent NU's organisational interests. Kastoyo, meanwhile, used a unique model of political representation. Selected to advance territorial ambitions and represent a particular social class, he presented himself as a nationalist who treated all residents equally, including minorities. This distinguished him from Agus Purnomo, who was seen as prioritising NU's organisational interests.

Contrasting the results of this study with those of previous research, it may be seen that political representation exists differently 
in the executive branch. Previous research into political representation in the executive branch have focused on gender (Koyuncu \& Sumbas, 2016) or identity (Nasrudin \& Nurdin, 2018). This study has found that territory, social class, and ideology-already identified in mainstream studies as part of political representation in legislaturealso contribute to political representation in the executive branch. More broadly, this study offers a means of understanding political representation from a different perspective.

This study has been limited in that it only discusses the process within the elections of a single village. As such, further research is necessary, as it may potentially not only identify similar models of political representation, but also new ones; it may even discover that models of political representation are not used in some cases.

This study has focused solely on political representation within the context of elections at the village level, emphasising its contribution to candidate selection. Unlike Nasrudin \& Nurdin (2018), it has not attempted to understand political representation's contribution to candidates' electoral victory or defeat. However, it is important to understand how models of political representation influence election results. Do different models have different effects on the number of votes received? This question, though small, requires an answer. It is thus hoped that the current study can help guide future research. 


\section{References}

Aguilar, R., Cunow, S., \& Desposato, S. (2015). Choice sets, gender, and candidate choice in Brazil. Electoral Studies, 39, 230-242.

Cahasta, L. A. (2017). Politik representasi rumah aspirasi: Studi tentang rumah aspirasi Budiman di Kabupaten Banyumas-Cilacap. Journal of Governance, 2(2).

Carnes, N., \& Lupu, N. (2015). Rethinking the comparative perspective on class and representation: Evidence from Latin America. American Journal of Political Science, 59(1), 1-18.

Celis, K. (2013). Representativity in times of diversity: The political representation of women. Women's Studies International Forum, 41, 179-186.

Ekawati, E. (2016). Dari representasi politik formal ke representasi politik non-elektoral. Jurnal Penelitian Politik, 11(2), 8.

Hasunuma, L. (2019). Beyond formal representation: Case studies of women's participation in civil society in Japan. Women's Studies International Forum, 72, 1-8.

Jennes, G., \& Persyn, D. (2015). The effect of political representation on the geographic distribution of income: Evidence using Belgian data. European Journal of Political Economy, 37, 178-194.

Khaldun, I. (2017). Demonstrasi dalam pemilihan Kepala Desa (Studi kasus desa dengan tipologi transisional, tradisional dan modern di Kabupaten Bima. Jurnal Ilmiah Mandala Education, 3(1), 326-341.

Koyuncu, B., \& Sumbas, A. (2016). Discussing women's representation in local politics in Turkey: The case of female mayorship. Women's Studies International Forum, 58, 41-50.

Kurebwa, J. (2015). A review of Hanna Pitkin's (1967) Conception of women's political representation. International Journal of Scientific and Research Publications, 5(11), 50-60.

Lühiste, M., \& Kenny, M. (2016). Pathways to power: Women's representation in the 2014 European parliament elections. European Journal of Political Research, 55(3), 626-641.

Martin, N. S. (2019). Ethnic minority voters in the UK 2015 General Election: A breakthrough for the Conservative Party?. Electoral Studies, 57, 174-185.

Nasrudin, J., \& Nurdin, A. A. (2018). Politik identitas dan representasi politik (Studi kasus pada Pilkada DKI periode 2018-2022). Hanifiya: Jurnal Studi Agama-Agama, 1(1), 34-47. 
Prihatini, E. S. (2019, January). Women who win in Indonesia: The impact of age, experience, and list position. Women's Studies International Forum, 72, 40-46.

Pitkin, H. F. (1967). The concept of representation. Oakland, USA: University of California Press.

Samadhi, W. P., \& Warouw, N. (2009). Demokrasi di atas pasir: Kemajuan dan kemunduran demokrasi di Indonesia. Demos: Jakarta.

Scott, H. V. (2009). Representation, politics of. In International Encyclopedia of Human Geography. Amsterdam: Elsevier, 351-357.

Suseno, N. (2013). Representasi politik. Jakarta: Puskapol UI.

Törnquist, O., Webster, N., \& Stokke, K. (Eds.). (2009). Rethinking popular representation. New York: Springer.

Van der Zwan, R., \& Lubbers, M. (2016). The political representation of ethnic minorities in the Netherlands: Nominated and elected ethnic minority candidates. ECPR Joint Sessions in Pisa, Italy, 13, $5-21$.

Zhanarstanova, M. B., \& Nechayeva, E. L. (2016). Contemporary principles of political representation of ethnic groups. Procedia Economics and Finance, 39, 76-82. 